\title{
Green Product Purchasing Phenomenon: Exploring the Gaps of Theoretical, Methodological and Empirical
}

\author{
${ }^{1}$ RAHAB, ${ }^{2}$ BASU SWASTHA DHARMMESTA, ${ }^{3}$ SAHID SUSILO NUGROHO \\ 4 YULIA ARISNANI WIDYANINGSIH \\ 1 Jurusan Manajemen, Fakultas Ekonomi dan Bisnis, Unsoed, Jl. HR Boenyamin 708, Grendeng, Purwokerto. \\ 2, 3, 4 Departemen Manajemen, Fakultas Ekonomi dan Bisnis, Universitas Gadjah Mada, Yogyakarta. \\ email: ${ }^{1}$ rahab_inc@yahoo.co.id; ${ }^{2}$ dharmmesta@ugm.ac.id; ${ }^{3}$ sahid@ugm.ac.id; ${ }^{4}$ yulia.widyaningsih@ugm.ac.id
}

\begin{abstract}
This study aims to identify research gaps on green purchasing topics and proposes several recommendations for future research. To explain the phenomenon of green products purchase, this study uses Theory of Planned Behavior (TPB) in framework. The research uses a qualitative method approach by conducting a review of articles that traced through four popular journal providers: Ebsco, J-Stors, Proquest and Emeraldinsight. A literature search process held between April, 2015 until Juni, 2015 and resulted on 67 chosen articles. The outcome of the review identified four theoretical gaps, two methodological gaps and one practical gap.
\end{abstract}

Keywords: green product purchasing, theoretical, TPB

\section{Introduction}

Green products consumption as a manifestation of consumer concern for health brings a significant impact to create demand for environmentally friendly products which will motivate manufacturers to produce green products. The growing of naturally healthy lifestyle lead to more environmentally friendly and natural products on market. Consumers begin to consider environmental issues when they do purchasing and consumption activity (Laroche, Bargeron, and Forleo, 2001). Facts which support the increasing of environmental awareness is the willingness to pay more for environmentally friendly products.

Several theories in social psychology, for example, norm activation theory (Schwartz, 1977), value belief norm (Stern, 2000), Theory of Reasoned Action (TRA) (Ajzen and Fishbein, 1980 in Sheppard et al.,1988) and Theory of Planned Behavior (Ajzen, 1991) has been widely used by researchers to predict and explain green consumption behavior phenomenon. However, this study decides to use TPB framework to explain the green consumption phenomenon. TPB uses attitude-behavior approach and positioning attitudinal variables are not exogenous but as mediation for other variables (Killbourne and Beckmann, 1998). This study aims to identify some gaps in green consumption literature both theoretically, methodologically and empirically. Identification of gaps is expected to provide opportunities for future research related to contemporary issues regarding green product purchasing.

\section{Theory of Planned Behavior}

One of theory that is widely used to investigate consumer behavior in green products purchasing is TPB. TPB can be used to explain human behavior and psychological determinants. TPB is development of the theory of reasoned action (theory of reasoned action / TRA). TPB or TRA, is a development model of the attitude-behavior relationship has been supported by many empirical studies (Kim and Hunter, 1993). TRA was originally developed by Ajzen and Fishbein (1980 Seppard et al., 1988), and has been widely used to investigate human behavior. TRA has a weakness because it

Received: July 19, 2016, Revision: October 10, 2016, Accepted: December 19, 2016

Print ISSN: 0215-8175; Online ISSN: 2303-2499. Copyright@2016. Published by Pusat Penerbitan Universitas (P2U) LPPM Unisba Accredited by DIKTI. SK Kemendikbud, No.040/P/2014, valid 18-02-2014 until 18-02-2019 
assumes that the behavior described as the whole of volitional control total. Although individuals have the intention to do the particular behavior, but not necessarily do such behaviors because of time constraints, limited resources and insufficient opportunities (Ajzen, 2002). TRA only applies to behavior based on her own accord (Zint, 2002).

TPB has been widely applied to predict the behavior of choosing green products. Cox, Anderson, Lean, and Mela (1998) revealed that TPB can explain from 33 percent to 47 percent of variance in intention to increase green products consumption. Next, TPB has also been applied to investigate food sustainable consumption behavior in context of organic food (Arvola, Vassallo, Dean, Lampila, Saba, Lähteenmäki, and Shepherd, 2008; Chen, 2007; Dean, Raats and Shepherd, 2008). While three predictors of intention on TPB are found to be significant predictors in this study, attitude is a major predictor, followed by subjective norms, and perceived behavioral control.

In a study that using TPB, intention to behave taken as a proxy measure of possible behavior (Ajzen, 2002). In reality, behavior will be influenced by intention to act that is likely to act. Behavior will be defined and distinguished from autonomous and nonvolitional behavior. Behavior will be defined as behavior which caused by the existence of information that has been adapted to the central nervous system, while the autonomous behavior is mainly determined by the genetic information and non-volational behavior is mainly determined by the chemical information and information in the nervous system that is not adjusted.

Some researchers have been widely applied TPB to predict intentions of individual behavior context (Ajzen, 2002). TPB has been used to describe specific behavior of individuals in certain circumstances, for example in restaurant (Cheng, Lam and Hsu, 2005) or when individual facing decision on purchasing items such as food transgenetic (O'Fallon, Gursoy, and Swanger, 2007). The results of several studies have demonstrated predictive power of TPB.

\section{Qualitative Approach on Literature}

This study used a qualitative approach that systematically examines some of the relevant literature from multiple providers based journals that can be accessed by researchers. Data were collected using a network provider journal of the UGM Library began in April, 2015 to June, 2015. The population of this study is all Englishlanguage articles which were found in 4 (four) providers include Ebsco journal, J-Stors, Proquest and Emeraldinsight. One article of the empirical research is a unit of analysis. The searching strategy of articles using the keywords: "TPB and Green behavior. The scope of this study is all the articles that meet the following criteria: (1) Articles can be found using the keyword: "TPB", "Green product", "Purchasing", "Proenvironmental" and "Green behavior", (2) Articles can be downloaded in the form of pdf files. Based on the search through journal provider 67 articles were obtained with distribution as follows, from Ebsco, 27 article, 9 articles from J-Stors, 17 articles from Proquest, and 14 articles of Emeraldinsight. From 67 articles hereafter performed review process related to model, variables, measurement and study sites. Results of study create categorization related to the research gaps include gaps in theoretical, methodological and practical.

\section{Analyzing of Research Gaps on Green Purchasing Behavior}

TPB is development of TRA (Ajzen and Madden, 1986), is one model social psychology domain that has been widely used to predict the behavioral intention by social psychologists (Armitage and Conner, 2001; Collins and Carey, 2007; Fielding et al.,2008 ). In the domain of intention to behave environmentally friendly, some researchers (Lam, 1999; Bamberg and Mozer, 2007; Chen and Tung, 2014) also uses TPB as a theoretical basis for understanding whether consumers intend to make eco-friendly behavior.

One of the strengths of the model related to TPB is parsimonious power. However, original model of TPB are not enough to shoot full complex individual behavior in some cases. Consequently, many researchers try to improve explanatory power of TPB by adding variety of variables as antecedent. Some studies combine or expand TPB with other determining factors in some research model (Chan and Bishop, 2013; Botetzagias, Fani, Dima and Malesios, 2014; Chen and Tung, 2014; Pakpour et al., 2014).

The results of searching associated with implementation of TPB in green consumption context have identified some gaps that allow for further research to develop a model of the original TPB by adding some external 
variables. The addition of variable is expected to improve predictive power of TPB. Based on literature review related to application of TPB model to predict purchasing environmentally friendly products behavior seven research gaps were obtained, which consists of four theoretical gaps, two methodological gaps and one empirical gap.

\section{The First Theoretical Gap: Subjective Norms and Attitudes}

The first gap of theoretical starts from studies conducted by Sheppard, Hartwick, and Warshaw (1988) on role of subjective norm in TPB model. A meta-analysis conducted by Sheppard et al. (1988) found that subjective norms are weak predictors of intention in the model TPB. Furthermore, Armitage and Conner (2001) conducted a meta-analysis also found that TPB and subjective norm is the weakest factor related to behavioral intention. As result, subjective norm accidentally deleted from several studies that use TPB. However, influence subjective norm to intention is still supported by some empirical studies and subjective norm is regarded as a key variable of TPB model (Trafimow and Finlay, 1996).

According to Chang (1998), inclusion way of influence of subjective norms to attitudes is needed to increase predictive power of TPB. This idea is also supported by results of several empirical studies (Kim et al., 2013; Han and Kim, 2010; Han et al., 2010; Ryu and Jang, 2006; Chang, 1998). For example, Ryu and Jang (2006) concluded that influence of others that are considered important by individuals (eg family, friends) on formation of attitude should not be overlooked. Kim et al. (2013) stated that establishment of attribution attitude influenced by references that are important to people such as family members, friends, co- workers, mass media, experts in a particular field, which in turn affects the formation of behavior. According to the twofactor of the theory of verbal conditioning which proposed by Insko and Cialdini (1969) stated that, normative information affecting one's attitude norms and also encourages individuals to hold posture for social approval is anticipated. This explains the relationship between structure of normative motivation and attitude.

Some researchers (among others, Han and Kim, 2010; Hrubes, Ajzen and Daigle, 2001) supports notion that process of social influence can have vital influence on formation of attitudes, while Hrubes et al., (2001) states that there are uses in separating between variable attitudinal and normative model of TPB although it is possible that variable attitudinal and normative correlated (Lewis, Agarwal, and Sambamurthy (2003). Lewis et al. (2003) stated that the stronger motivation of individual to conform to norms of a group, the stronger impact group behavior affect individual attitude. Referring to findings of inconsistencies related to influence of subjective norm on intention, it is necessary to investigate whether subjective norms influence intention to consume green products directly or indirectly through attitude on green product purchasing behavior.

\section{The Second Theoretical Gap: Relationship between Subjective Norms and Attitude}

Several previous studies has been using model of TPB in research on green consumption. A lot of them has been criticized by some researchers because it also has not incorporated the influence of moral or normative aspects on the model TPB (Leeuw, Valois, and Houssemand 2011; Rivis, Sheeran, and Armitage, 2009; Shepherd, Magnusson and Sjödén, 2005). However, several other researchers (Kaiser and Scheuthle, 2003; Kaiser et al., 2005; Kaiser, 2006) expressed doubt that moral norms can be a proxy or factors that may affect the intention to behave environmentally friendly.

In context of environmentally friendly behavior models, TPB has been tested in explaining the phenomenon of green consumption (Chen and Tung, 2014; Chan and Bishop, 2013; Han and Hansen, 2012; Chen and Tung, 2014; Botetzagias et al., 2014). However, despite generalization usefulness of TPB in predicting behavioral intentions are tested, several studies trying to improve the explanatory power of theory by adding TPB constructs in model. Several previous studies suggested that personal feeling of moral responsibility needed to be considered when testing willingness of individuals to perform certain behaviors (Gorsuch and Ortberg, 1983; Schwartz and Tessler, 1972). Shepherd et al. (2005) suggest that model of TPB should include moral aspects to capture the behavior of purchasing green products. Moral norms are individual perceptions of moral correctness or incorrectness of doing a particular behavior (Ajzen, 1991). Moral norms also mean responsibility perceived moral or personal norms. According to 
Manstead (2000) in Godin, Conner and Sheeran (2005) moral norm is the conviction of individuals to act in a certain way which is closely related to the "right" or "wrong", regardless of personal consequences or social consequences. The concept of moral norms, personal norm and moral responsibility has been widely used interchangeably in several previous studies.

Godin, et al., (2005) stated that predictive capacity of moral norms of behavior depending on type of behavior. Rivis, Sheran and Armitage (2009) states that moral norm will strengthen individual intentions to perform behaviors that have consequences on others. Chen and Tung (2010) developed a model of TPB expansion by combining moral norms and consequences of recycling to explain intentions of consumer cycle. Research results show that model can explain expansion of consumer intentions to recycling. In addition, Chen and Tung (2010) found that the addition of moral norms on the model of TPB able is to increase total of variance of recycling intention. Beck and Ajzen (1991) in Kaiser and Scheuthle (2003) asserts that moral responsibility should be included in an issue of moral consideration to improve predictive power of TPB. In context of proenvironmental behavior, Kaiser and Scheuthle (2003) states that moral dimension that is included in the model TPB positively affect the conservation consumer behavior intention. Chen and Tung (2014) in his research found that green consumption behavior is behavior that contains elements of personal morality and social responsibility. The addition of moral norms on the original model TPB can improve the predictive power of the model TPB in predicting individual intention to make a purchase on green products.

\section{The Third Theoretical Gap: Environmental concern and Green Purchasing Behavior}

Dunlap and Van Liere (1978) defines environmental concern as awareness of environmental issues, as well as a desire to support and contribute personally to the handling of environmental problems. Environmental concern is constructed that has had an important role in predicting the behavior of pro-environment. The relationship between environmental concerns with proenvironmental behavior showed discrepancies findings. Some previous findings indicate that the influence of environmental concern with the behavior of pro-environment are significant
(Angelovska, Sotiroska and Angelovska, 2012; Bertrandias and Gambier, 2014), while other findings show that environmental awareness has a weak influence on the intention to behave environmentally friendly and eco-friendly behavior (Cleveland et al., 2005; Steg et al., 2011).

Ajzen and Fishbein (1980) proposed that general attitude such as concern for the environment can not directly affect intention, but indirectly. Bamberg (2003) states that environmental concern is to represent the general attitude and do not directly affect specific behaviors. Bamberg (2003) also confirms that awareness of individuals in environment will affect specific behaviors through attitudes and beliefs on the specific situation. Environmental concern is general attitude towards environment (Dunlap and Van Liere, 1978; Weigel and Weigel, 1978) and as a key factor that can make a person change their behavior to behave more environmentally friendly (Hansla et al., 2008; Bamberg, 2003; Fransson and Gørling, 1999; Dunlap and Van Liere, 1978; Weigel and Weigel, 1978). Several previous studies have revealed that consumers who care about the environment will have a positive the attitude on the products or services that are environmentally friendly (Aman et al., 2012; Han et al., 2009; Kim and Han, 2010). Attempts to explain why there is a weak correlation between environmental awareness and green consumption behavior is an important thing to be explored theoretically because environmental concerns are considered to have an important role in the study of the behavior of green consumption.

\section{The Fourth Theoretical Gap: Environmental knowledge and Green Purchasing Behavior}

Theoreti cally, knowledge of the environment plays an important role in predicting the behavior of pro-environment, however, some empirical findings indicate that the relationship between environmental knowledge to conduct pro-environment still showed findings that are inconsistent (Zsóka et al., 2012; Kaiser and Fuhrer, 2003; Laroche et al., 2001). Some research suggests that environmental knowledge is a significant predictor of environmentally friendly behavior, while other studies reported no significant rel ati onshi $p$ betw een en vi ronmental knowledge and pro environment behavior. Research Maloney and Ward (1973) showed that the ecological knowledge does not 
significantly influence the ecological behavior. Meta analysis conducted by Hines et al. (1987) found the average correlation between knowledge and behavior of the environment 0.30 . It shows that the correlation between knowledge and behavior of the environment is weak. In contrast, other studies have found that knowledge of the environment is a significant predictor of environmentally friendly behavior (Kanchanapibul et al., 2013; Mobley et al., 2010). Amyx et al. (1994) found that individuals with a high level of knowledge about environmental issues are more willing to pay a premium price for green products. In addition, Kaiser et al. (1999) revealed that environmental knowledge and environmental values explained 40 percent of the variance of special ecological behavioral intention, which in turn, explained 75 percent of variance general ecological behavior.

TPB is value expectancy theory. This theory assumes that individuals perform certain behaviors that are basically rational and deliberate in trying to maximize their satisfactionincexchange. Individuals make rational decisions and consider the consequences of their behavior before they make a decision to bring it to an action or not (Ajzen and Fishbein, 1980). In making a purcha $s$ e decision, consumers need an adequate knowledge related to the product or service. Knowledge is recognized in consumer research as characteristics that affect all stages in the decision making process (Laroche et al., 2001). Based on that idea, the strong suspicion that the environmental knowledge has contributed to the attitude and intention to purchase green products.

\section{The First Methodological Gap: Green Product Purchase Behavior}

Based on searching of articles, there are 2 (two) important issues related to aspects of methodological gaps. The first methodological issues related to measurement variable of environ $\mathrm{m}$ ental concern. The relatively weak re I ationship between environmental concerns with pro environmental behavior allegedly linked to construct the measure ment of environmental concern. To improve the strength of the relationship between environmental concerns with proenvironmental behavior, an appropriate strategy is made which called measurement strategy of constructs. Improper measurement strategy in the construct of environmental awareness can not adequately capture psychological processes underlying concern and will likely only worsen and create a low assessment of the relationship. Stern, Common, and Barbier (1996) argues that there are no standard instruments of the construct of environmental awareness that is stable and strong, it encoura $g$ es researchers to develop its own size and or using measures related to other theories that are considered conceptually has similarities with the constructs environmental awareness.

Measurements concerning environmental concern since 1970, mostly using two approaches, attitudes the value approach. Both approaches use different assumptions. Attitude, approach to conceptualizing the construct of environmental concern as a construct that contains both an eva I uation of the objects related to enviro $n$ mental issues as well as their owners $h$ ip of some beliefs/behaviors that are relevant to their interest in environmental issues. In attitude, approach, the construct of environmental awareness has similarities with the concept of environmental attitudes or general attitude (Bamberg, 2003). Some researchers measure the environmental awareness by using attitude, approach, among others, Thompson and Barton (1994), Bamberg (2003).

The value approach defines environmental concern as a construct that contains the type of a specific value or a specific value orientation, and values are often seen as a determinant of attitudes or filters attitudes towards environmental issues. Some researchers measure the environmental awareness by using a value approach, among others, Schultz et al. (2005), Stern (2000), Stern and Dietz (1994), Stern et al. (1999).

Both approaches (attitudes or values) in measuring environmental concerns still show the predictive power of the proenvironmental behavior which is still weak. In the seminal meta analysis conducted by Hines et al. (1987) showed that the relationship between environmental awareness and proenvironmental behavior of $r=0.37(\mathrm{~N}=9$ studies). In another study, Bamberg and Moser (2007) reported that the average correlation between environmental attitudes and environmental behavior of 0.42 with the number of studies that analyzed totaled 17. Testing of constructs that combine environmental awareness and environmental attitude indicator show the value of a relatively small variance in explains proenvironmental behavior ( $r 2=13.6$ to 17.6 percent of variance explained). Attempts to 
explanation why there is a weak correlation between environmental awareness and pro-environmental behavior are important both theoretically and practically because environmental concerns are considered to have an important role in the study of the environmental behavior. The use of different measurement on the construct of suspected environmental concerns has different influences on the behavior of the green. In order to improve ability of construct of environmental concerns in explaining behavior of green purchasing, research can be done by combining both perspectives (attitudes and values) to measure the construct of environmental awareness.

\section{The Second Methodological Gap}

The second methodological issues related to measurement of environmental knowledge variable. Abstract environmental knowledge is more likely to influence the actions of pro-environment than concrete knowledge. Until now there has been no explanation deemed sufficient to address these gaps. Schahn and Holzer (1990) identified two types of environmental knowledge to assess the environmental behavior: abstract (knowledge of environmental issues, problems, causes, solutions) and behavioral knowledge of concrete (such as factual knowledge). Tanner and Kast (2003) also reported that knowledge of the range of actions related to environment is more likely related to purchase of green food, while factual knowledge is not a predictor of green food purchases. In analysis of 128 previous studies, Hines et al. (1987) stated that abstract knowledge is most significant in predicting environmental actions.

Kaizer, Frick and Wilson (2004) identified three forms of knowledge to understand ways of knowledge which work together in promoting conservation behavior. Keizer et al. (2004) suggested that knowledge of the environment consists of three types: First, knowledge of the system, i.e knowledge related to ecosystem around him. This knowledge is closely related to the environmental knowledge on base level. Second, knowledge related to behavior, defined as knowledge related to what to do about environmental issues. This knowledge is higher than level of knowledge system. Third, the effectiveness of knowledge, i.e. knowledge about the benefits (effectiveness) of the act environmentally responsible. In this case, individual will choose some action that is likely to get the greatest environmental benefits. This knowledge is the knowledge of highest level compared to previous two types of environmental knowledge.

Several previous studies show that environmental knowledge construct measurement which some researchers only use one of types of knowledge (eg, Gambro and Switzky, 1999; Leeming, Dwyer, and Bracken, 1995) or, at most only two forms of environmental knowledge (eg, Hineset al .,1987). Therefore, the findings of these studies tend to be inconsistent, inclusive and varied in predicting behavior related to environmental conservation. In additional, environmental knowledge construct measurement with only one or two forms of knowledge did not describe comprehensively deals with environmental knowledge concept. Therefore, this study will use three forms of knowledge in measuring construction of environmental knowledge. The use of three forms of knowledge combined together are expected to acquire better reflection than one type of knowledge environment.

\section{Empirical Gap in Green Product Purchasing Behavior}

Empirical gaps are related to green consumption research in developing countries, especially Indonesia. Research on green products consumption mostly carried out in developed countries by the level of infrastructure, availability of products, and commitment to better government than developing countries. Research on green consumption based on the literature review in developing countries is still relatively rare. Factors which influence individual background (knowledge, moral norms and environmental knowledge) in encouraging changes in the behavior of individuals to engage in conduct pro-environment has been studied extensively in the United States and other developed countries with average consumer that has had better environmental awareness.

Lack of studieson effect of background factors of individual purchase behavior in developing countries may hinder understanding of essence of consumer behavior on sustainable consumption. Therefore, understanding impact of these factors on behavior of green products purchasing in developing countries like Indonesia, will help researchers to get better definition and illustration upon the environmentally conscious consumer behavior 
in different cultural contexts. Until so far, it is based on initial observations from the literature search that can be accessed by researchers in Indonesia, with the result that green purchasing is still in its early stages and ecological knowledge is still relatively limited compared to some developed countries.

\section{Conclusions}

Based on the theoretical aspects, the study of purchasing behavior still provides development opportunities for external variables of main model TPB. Variable of moral norms, environmental knowledge and environmental awareness is thought to have contributed to increasing the explanatory power of TPB in explaining green purchasing. Methodologically, the study of green consumption is still open opportunities which associated with use of indicators of constructs that are closely related to the theme of green consumption, which among others, are the construction of an environmental awareness and environmental knowledge.

Characteristics differences of each country or region from the aspect of culture, demographics, infrastructure and availability of products between developed countries and developing countries, give an opportunity for researchers to conduct empirical research on the consumption of green with Indonesia. Good research explains the gaps of theoretical, methodological, and empirical which expected to provide an opportunity for other researchers in the future to conduct empirical testing of some of the gaps that have been described previously.

\section{References}

Ajzen, I., \& Fishbein, M (1980), Understanding attitude and predicting social behavior, Englewood Cliffs, NJ: Prentice- Hall.

Ajzen, I., \& Madden, T. J. (1986), "Prediction of goal-directed behavior: Attitudes, intentions, and perceived behavioral control," Journal of experimental social psychology, 22(5), 453-474.

Ajzen, I. (1991), "The theory of planned behavior," Organizational Behavior and Human Decision Processes, 50(2), 179211.

Ajzen, I. (2002), "Perceived behavioral control, self-efficacy, locus of control, and the theory of planned behavior", Journal of Applied Social Psychology, 32, 665-683.

Aman, A.H.L., Harun, A., Hussein, Z. (2012),
"The influence of environmental knowledge and concern on green purchase intention the role of attitude as a mediating variable," British Journal of Arts and Social Sciences , 7 (11), 145-167.

Amyx D, De Jong $P$, Lin $X$, Chakrabotry $G$, Wiener $L$, "Influencers of purchase intentions for ecologically safe products: An exploratory study," Marketing Theory and Applications, Proceedings on the 1994 AMA Winter Educators Conference; 1994. p. 341-347.

Angelovska, J., Sotiroska, S. B., \& Angelovska, N. (2012), "The impact of environmental concern and awareness on consumer behavior," Journal of International Environmental Application and Science, $7(2), 406$.

Armitage, C. J., \& Conner, M. (2001), "Efficacy of the theory of planned behaviour: A metaàanalytic review", British Journal of Social Psychology, 40(4), 471-499.

Arvola, A., Vassallo, M., Dean, M., Lampila, P., Saba, A., Lähteenmäki, L., \& Shepherd, R. (2008), " Predicting intentions to purchase organic food: The role of affective and moral attitudes in the theory of planned behaviour," Appetite, 50(2), 443-454.

Bamberg, S. (2003), "How does environmental concern influence specific environmentally related behaviors? A new answer to an old question," Journal of Environmental Psychology, 23 (1), 21-32.

Bamberg, S., \& Möser, G. (2007), "Twenty years after Hines, Hungerford, and Tomera: A new meta-analysis of psychosocial determinants of pro-environmental behaviour," Journal of Environmental Psychology, 27(1), 14-25.

Beck, L., \& Ajzen, I. (1991). "Predicting dishonest actions using the theory of planned behavior," Journal of research in personality, 25(3), 285-301.

Bertrandias, L., \& Elgaaied-Gambier, L. (2014), "Others' environmental concern as a social determinant of green buying," Journal of Consumer Marketing, 31(6/7), 417-429.

Botetzagias, I., Dima, A. F., \& Malesios, C. (2014), "Extending the Theory of Planned Behavior in the context of recycling: the role," Human Ecology Review, 18(1), 30.

Chan, L., \& Bishop, B. (2013),"A moral basis for recycling: Extending the theory of planned behaviour," Journal of Environmental Psychology, 36, 96-102.

Chang, M. K.(1998), "Predicting unethical behavior: a comparison of the theory of reasoned action and the theory of planned 
behavior," Journal of Business Ethics, $17(16), 1825-1834$.

Chen, M. F. (2007), "Consumer attitudes and purchase intentions in relation to organic foods in Taiwan: Moderating effects of food-related personality traits," Food Quality and Preference, 18(7), 10081021.

Chen, M. F., \& Tung, P. J. (2010), "The Moderating Effect of Perceived Lack of Facilities on Consumers' Recycling Intentions," Environment and Behavior, 42 (6), $824-844$.

Chen, M. F., \& Tung, P. J. (2014), "Developing an extended Theory of Planned Behavior model to predict consumers' intention to visit green hotels," International Journal of Hospitality Management, 36, 221-230.

Cheng, S., Lam, T., \& Hsu, H.C. (2005), "Testing the sufficiency of the theory of planned behavior: a case of customer dissatisfaction responses in restaurants," Journal of Hospitality Management, 24, 475-792.

Cleveland, M., Kalamas, M., \& Laroche, M. (2005), "Shades of green: linking environmental locus of control and proenvironmental behaviors," Journal of Consumer Marketing, 22 (4), 198-212.

Collins, S. E., \& Carey, K. B. (2007), "The theory of planned behavior as a model of heavy episodic drinking among college students," Psychology of Addictive Behaviors, 21(4), 498.

Cox, D. N., Anderson, A. S., Lean, M. E., \& Mela, D. J. (1998), "UK consumer attitudes, beliefs and barriers to increasing fruit and vegetable consumption," Public Health Nutrition, 1 (1), 61- 68.

Dean, M., Raats, M. M., \& Shepherd, R. (2008), "Moral concerns and consumer choice of fresh and processed organic foods," Journal of Applied Social Psychology, 38(8), 2088-2107.

Dunlap, R.E., \& van Liere, K.D. (1978), "The new environmental paradigm," Journal of Environmental Education, 9 (4), 10-19.

Fielding, K. S., Terry, D. J., Masser, B. M., \& Hogg, M. A. (2008), "Integrating social identity theory and the theory of planned behaviour to explain decisions to engage in sustainable agricultural practices," British Journal of Social Psychology, 47(1), 23-48.

Fransson, N., \& Gärling, T. (1999), Environmental concern: Conceptual definitions, measurement methods, and research findings," Journal of Environmental Psychology, 19 (4), 369-
382.

Gambro, J. S., \& Switzky, H. N. (1999), "Variables associated with American high school students' knowledge of environmental issues related to energy and pollution," Journal of Environmental Education, 30 (2), 15-22.

Godin, G., Conner, M., \& Sheeran, P. (2005), "Bridging the intention-behaviour gap: The role of moral norm," British Journal of Social Psychology, 44(4), 497-512.

Gorsuch, R. L., \& Ortberg, J. (1983), "Moral obligation and attitudes: Their relation to behavioral intentions," Journal of Personality and Social Psychology, 44(5), 1025-1028.

Han, H., Hsu, L.-T., Lee, J.S. (2009), "Empirical investigation of the roles of attitudes Towards green behaviors, overall image, gender, and age in hotel customers' eco-friendly decision making process," International Journal of Hospitality Management, 28,519-528.

Han, H., \& Kim, Y. (2010), "An investigation of green hotel customers' decision formation: Developing an extended model of the theory of planned behavior," International Journal of Hospitality Management, 29(4), 659-668.

Han, H., Hsu, L., \& Sheu, C. (2010), "Application of the theory of planned behavior to green hotel choice: Testing the effect of environmental friendly activities," Tourism Management, 31, 325-334.

Han, Y., \& Hansen, H. (2012), "Determinants of sustainable food consumption: A meta analysis using a traditional and a structural equation modelling approach," International Journal of Psychological Studies, 4(1), p22.

Hansla, A., Gamble, A., Juliusson, A., \& Gärling, T. (2008), "Psychological determinants of attitude towards and willingness to pay for green electricity," Energy Policy, 36 (2), 768-774.

Hines J, Hungerford $H$, Tomera A. (1987), "Analysis and synthesis of research on environmental behaviour: a metaanalysis," Journal Environmental Education, 18(2), 1-8.

Hrubes, D., Ajzen, I., \& Daigle, J. (2001), "Predicting hunting intentions and behavior: An application of the theory of planned behavior", Leisure Sciences, 23(3), 165-178.

Insko, C. A., \& Cialdini, R. B. (1969), "A test of three interpretations of attitudinal verbal reinforcement," Journal of Personality and Social Psychology, 12(4), 333. 
Kaiser, F. G., Ranney, M., Hartig, T., \& Bowler, P. A. (1999), "Ecological behavior, environmental attitude, and feelings of responsibility for the environment," European Psychologist, 4 (2), 59-74.

Kaiser, F. G., \& Fuhrer, U. (2003), "Ecological behavior's dependency on different forms of knowledge," Applied Psychology, 52(4), 598-613.

Kaiser, F.G., Scheuthle, H. (2003), "Two challenges to a moral extension of the theory of planned behavior: moral norms and just world beliefs in conservationism," Personal Individual Difference, 35, 10331048.

Kaizer F.G., Frick J., Wilson M. (2004), "Environmental knowledge and conservation behavior: exploring prevalence and structure in a representative sample," Personality and Individual Differences, 37, p.1597-1613.

Kaiser, F.G., Hübner, G., Bogner, F.X. (2005), "Contrasting the theory of planned behaviour with value belief-norm model in explaining conservation behavior," Journal Applied Psychology, 3510, 2150-2170.

Kaiser, F.G. (2006), "A moral extension of the theory of planned behavior: norms and anticipated feelings of regret in conservationism," Personal Individual Differ, 41, 71-81.

Kanchanapibul, M., E. Lacka, X. Wang, H. K.Chan. (2013), "An empirical investigation of green purchase behaviour among the young generation," Journal of Cleaner Production, 66, pp: 528 - 536.

Kilbourne, W. E., \& Beckmann, S. C. (1998), "Review and critical assessment of research on marketing and the environment," Journal of Marketing Management, 14(6), 513-532.

Kim, M. S., \& Hunter, J. E. (1993), "Relationships among attitudes, behavioral intentions, and behavior: A meta-analysis of past research, part 2," Communication Research, 20, 331-364.

Kim, Y., Han, H., (2010), "Intention to pay conventional-hotel prices at a green hotel-a modification of the theory of planned behavior," Journal of Sustainable Tourism , 18 (8), 9971014.

Kim, E., Ham, S., Yang, I. S., \& Choi, J. G. (2013), "The roles of attitude, subjective norm, and perceived behavioral control in the formation of consumers' behavioral intentions to read menu labels in the restaurant industry," International Journal of Hospitality Management, 35, 203-213. Lam, S. P. (1999), "Predicting intentions to conserve water from the theory of planned behavior, perceived moral obligation, and perceived water right.," Journal of Applied Social Psychology, 29(5), 1058-1071.

Laroche, M., Bergeron, J., \& Barbaro-Forleo, G. (2001), "Targeting consumers who are willing to pay more for environmentally friendly products," Journal of Consumer Marketing , 18 (6), 503-520.

Leeming, F. C., Dwyer, W. O., \& Bracken, B. A. (1995), "Children's environmental attitude and knowledge scale: Construction and validation," Journal of Environmental Education, 26 (3), 22-31.

Leeuw, A., Valois, P., \& Houssemand, C. (2011), "Predicting the intentions to buy fairtrade products: The role of attitude, social norm, perceived behavioral control, and moral norm," OIDA International Journal of Sustainable Development," 2 (10), 77- 84

Lewis, W., Agarwal, R., \& Sambamurthy, V. (2003), "Sources of influence on beliefs about information technology use: An empirical study of knowledge workers," MIS Quarterly,vOl. 27, No.4, 657-678.

Maloney, M. P., \& Ward, M. P. (1973), "Ecology: Let's hear from the people: An objective scale for the measurement of ecological attitudes and knowledge," American Psychologist, 28(7), 583.

Mobley, C., Vagias, W.M., DeWard, S.L. (2010), "Exploring additional determinants of environmentally responsible behaviour: the influence of environmental literature and environmental attitudes", Environmental Behavior, 42 (4), 420-447.

O'Fallon, M. J., Gursoy, D., \& Swanger, N. (2007), "To buy or not to buy: Impact of labeling on purchasing intentions of genetically modified foods," International Journal of Hospitality Management, 26, 117-130.

Pakpour, A. H., Zeidi, I. M., Emamjomeh, M.M., Asefzadeh, S., \& Pearson, H (2014), "Household waste behaviours among a community sample in Iran: An application of the theory of planned behaviour," Waste management, 34(6), 980-986.

Rivis, A., Sheeran, P., \& Armitage, C. J. (2009), "Expanding the affective and normative components of the theory of planned behavior: A metaàanalysis of anticipated affect and moral norms," Journal of Applied Social Psychology, 39(12), 2985- 3019.

Ryu, K., \& Jang, S. S. (2006), "Intention to experience local cuisine in a travel destination: The modified theory of 
reasoned action," Journal of Hospitality \& Tourism Research, 30(4), 507516.

Schahn, J., \& Holzer, E. (1990), "Studies of environmental concern: the role of knowledge, gender and background variables," Environment and Behavior, 22, 767-786.

Schultz, P. W., Gouveia, V. V., Cameron, L.D., Tankha, G., Schmuck, P., \& Franěk, M (2005), "Values and their relationship to environmental concern and conservation behavior," Journal of Cross-Cultural Psychology, 36 (4), 457-475.

Schwartz, S. H., \& Tessler, R. C. (1972), "A test of a model for reducing measured attitude behavior discrepancies," Journal of Personality and Social Psychology, 24 (2), 225.

Schwartz, S. H. (1977), "Normative influences on altruism," Advances in Experimental Social Psychology, 10, 221-279.

Shepherd, R., Magnusson, M., \& Sjödén, P.O. (2005), "Determinants of consumer behavior related to organic foods," AMBIO: A Journal of the Human Environment, 34(4), 352-359.

Sheppard, B. H., Hartwick, J., \& Warshaw, P. R. (1988). "The theory of reasoned action: A meta-analysis of past research with recommendations for modifications and future research," Journal of consumer research, 15(3), 325-343.

Steg, L., De Groot, J. I., Dreijerink, L., Abrahamse, W., \& Siero, F. (2011), "General antecedents of personal norms, policy acceptability, and intentions: The role of values, worldviews, and environmental concern," Society and Natural Resources, 24 (4), 349-367.

Stern, P. C., \& Dietz, T. (1994), "The value basis of environmental concern," Journal of Social Issues, 50 (3), 65-84.
Stern, P. C., Dietz, T., Abel, T., Guagnano, G.A., \& Kalof, L. (1999), "A value-belief-norm theory of support for social movements: The case of environmentalism," Human Ecology Review, 6 (2), 81-98.

Stern, P. C. (2000), "New environmental theories: toward a coherent theory of environmentally significant behavior," Journal of social issues, 56 (3), 407-424.

Tanner, C., \& Kast, S. W. (2003), "Promoting sustainable consumption: Determinants of green purchases by Swiss consumers," Psychology and Marketing, 20(10), 883902.

Thompson, S. C. G., \& Barton, M. A. (1994), "Ecocentric and anthropocentric attitudes toward the environment," Journal of environmental Psychology, 14 (2), 149157.

Trafimow, D., \& Finlay, K. A. (1996), "The importance of subjective norms for a minority of people: Between subjects and within-subjects analyses," Personality and Social Psychology Bulletin, 22(8),820828.

Weigel, R. \& Weigel, J. (1978), "Environmental concern: the development o $f$ a measurement," Environment and Behavior, 10, pp. 3-15.

Zint, M. (2002), "Comparing three attitudebehavior theories for predicting science teachers' intentions, "Journal of Research in Science Teaching, 39 (9), 819-844.

Zsóka, A., Szerényi, Z., Széchy, A., Kocsis, T. (2012), "Greening due to environmental education? Environmental knowledge, attitudes, consumer behaviour and everyday pro-environmental activities of Hungarian high school and university students," Journal of Cleaner Production, 48, 126-138. 